\title{
Journalistic and Commercial News Values
}

\author{
News Organizations as Patrons \\ of an Institution and Market Actors
}

\author{
Sigurd Allern
}

Why do some events fill the columns and air time of news media, while others are ignored? Why do some stories make banner headlines whereas others merit no more than a few lines? What factors decide what news professionals consider newsworthy? Such questions are often answered - by journalists and media researchers alike - with references to journalistic news values or 'news criteria'. Some answers are normatively founded; others are pragmatic and descriptive. In the present article, I submit that editorial priorities should not be analyzed in purely journalistic terms. Instead, they should be seen as efforts to combine journalistic norms and editorial ambitions, on the one hand, with commercial norms and market objectives, on the other.

\section{Commercial Enterprise and Patron of an Institution}

News media have a dual nature. On the one hand they represent a societal institution that is ascribed a vital role in relation to such core political values as freedom of expression and democracy. On the other hand, they are businesses that produce commodities - information and entertainment - for a market.

At the same time, because their products are descriptions of reality that influence our perceptions of the world around us, news media wield influence that extends far beyond the marketplace. Who controls the media is of significance to every member of society. As figures like Rupert Murdoch, Silvio Berlusconi and the new Russian media barons remind us, control of the media is a key to political power. And while many venerable industries wither and die (or undergo profound metamorphoses) the consciousness industry - as writer Hans Magnus Enzensberger (1974) dubbed the media and other actors in the communication sector - is rapidly expanding.

Newspapers, radio programs and television transmissions differ with respect to how consumption of them affects our perception and understanding of reality. As Graham Murdoch observes:

By providing accounts of the contemporary world and images of the 'good life', they play a pivotal role in shaping social consciousness, and it is this 'special relationship' between economic and cultural power that has made the issue of 
their control a continuing focus of academic and political concern (Murdoch 1982:118).

The chief news media are newspapers, news magazines, radio and television stations that carry newscasts, news bureaux and web-newspapers and newsletters. The boundaries visà-vis other media are sometimes fluid, however, and in practice very few media are pure news organizations. Besides news, reportage, comment and debate, newspapers also contain features, 'human interest stories' and pure entertainment; in Norwegian television, news fills less than 20 per cent of total transmission time on both state-owned public service television, NRK Fjernsynet, and commercially financed TV2. Common to all news media, however, is that news is a vital element in their overall content 'mix'.

In market terms, news media are enterprises that produce and distribute media products over well-defined regions and fields. Take, for example, a company that publishes a printed newspaper. Today, the situation is often more complicated: a group company may own several news enterprises, which may operate within different media, such as the press, radio and television. Many printed newspapers also publish a net edition; in some cases these are organized as independent companies. In the present discussion the term, news enterprise designates companies having direct responsibility for journalistic publishing and known for their news and other output of topical material.

What distinguishes news media from other media, and news enterprises from other enterprises, is primarily their links to journalism and news as a societal institution. Timothy Cook (1998) distinguishes three central characteristics of institutions in general, and of media institutions in particular. ${ }^{1}$

First of all, institutions are social patterns of behaviour common to the organizations operating in a given sector of society. These include tacit procedures, routines and conditions that can both expand and constrain the room for maneuver. Such rules and procedures become internalized and are perceived as more or less natural ways to go about doing things.

If we then consider news media in this perspective, it becomes clear that regardless of the organization, there is a common understanding of certain basic genre rules that news reporting must observe and conventions regarding what is relevant and how it should be presented. This understanding is also reflected in both sources' and the public's expectations and requirements. News desks solve the problem by establishing certain routines for surveillance and news gathering in certain areas and through decisions concerning frameworks for the content 'mix', page or program editing, and design. Reporters are forced, as Gaye Tuchman (1973) so aptly put it, to "routinize the unexpected". News stories are generally presented in familiar wrappings.

Another characteristic of institutions is that they extend over space and endure over time. "Institutions by definition are the more enduring features of social life," as Anthony Giddens (1984:24) observes. News enterprises differ with respect to their size, geographical locality, orientation toward their audiences, technology and financing; they were established at different points in time and have different political histories. Newspapers and magazines were once alone among modern news media; then radio arrived on the scene, followed by television and now net media. Some news organizations fade away, and new ones see the light of day.

At the same time, an institutional 'sisterhood' among the media has evolved over the years. Among the common features are ethical norms and understandings of what constitutes "good journalistic practice" that apply to all media and media organizations. 
Another common feature is the development of specialized training, which successively has elevated journalism to the status of a quasiprofession.

A third characteristic of institutions is that they are expected - by practitioners in the organizations within the institutions and others - to perform certain tasks and fill certain needs in society and politics.

Here we come to one of the most clearly institutional features of news media, namely, their roles as channel and arena for communication in the public sphere. Various commissions and committee reports on Swedish and Norwegian media speak of roles that are perequisite to the proper functioning of democracy: public affairs information, scrutiny of wielders of power, and public debate. Political parties and elites have long viewed news media as important channels by which to reach the electorate and as competitive arenas for political opinion formation. Ideals relating to these roles are expressed, for example, in the code of ethics of the Norwegian Press Association that stresses the functions of information, debate and critical scrutiny. The notion of journalism as a mission, a task for the benefit of society has become a central part in the ideology of journalism. ${ }^{2}$ It is, as Odd Raaum (1999:65) points out, a myth that confers legitimacy on journalism as an occupation and enterprise.

By virtue of this myth or rationale, media companies are respected as patrons of the institution of news. Knut Helland describes the network of institutional linkages surrounding news media, as follows: "It is in the tension between performing idealized societal functions and serving up attractive products on the market that news reporting evolves as productional practices, as texts and as objects of interpretation" (Helland 1999:189). In an institutional perspective journalism cannot be considered a uniform or monolithic force or collective player. Institutions are complex and allow room for conflicting interpretations, priorities and solutions. How news companies and news desks perform their 'custodial' role in practice depends on numerous factors, e.g., the economic resources at their disposal and their relations to multiple markets: the stock market, advertising, the information market and users.

\section{Tracking News Values}

News is produced under different conditions, often in haste, and by people who may have different ideas as to what is important. Unexpected events - such as a journalist calling in sick - can influence editorial priorities: a story that surely would have been covered might be ignored due to a single reporter's illness. A major fire or accident may cause any number of other stories to be shoved aside. On slow days, on the other hand, stories that might normally merit little attention may be played up as major events. One might say that the news threshold on such occasions is a notch or two lower.

Still, there is a system to these seemingly chance occurrences. One frequently hears the phrase that news values are "in the woodwork", that is to say, that it is a question of a tacit newsroom culture that newcomers quickly absorb and internalize.

One of the causes - and journalists tend, for professional-ideological reasons, to stress this - is that certain values, occupational norms and work routines affect the news selection process. Statements about what constitutes "good journalism" often refer to codes of ethics and ideological notions of social responsibility, e.g., journalists' ideas about their role as patrons of the news institution. The duty to provide information about important social issues and to train spotlights on wrongdoing and lapses is commonly subscribed to. 
Textbooks on journalism (Mencher 1994; Østlyngen \& Øvrebø 1998) link news values like these to words like significance (the relevance and importance of the event or phenomenon to readers), identification (geographical or cultural proximity), sensation (the element of surprise), timeliness (proximity in time), and conflict (controversy, confrontation). Last, but certainly not least, the salience (familiarity, prominence) and influence of the country, institution or person in the news story. In his book on television journalism, Olav Njaastad (1999:36) speaks of proximiy as the one most central criterion, and he discusses several dimensions: proximity in time, proximity of effects or consequences, geographical proximity, cultural proximity and emotional proximity.

Such criteria arise out of both journalistic norms and practical experience of news reporting. At the same time, they are relatively general and abstract, which may give the impression that they are constants, independent of time and place. But news reporting and editing are always a question of evaluating specific things. Judgments of "newsworthiness" will always vary between news desks, and they will change over time.

Two models of news gathering are generally used when describing the news production process. In the one case, the news desk is said to make a selection among the flow of events, etc., that take place. 'The news' consists of the events that were selected. News editors have been likened to 'gatekeepers', a term coined by David Manning White (1950) in his landmark study of work routines within an American newspaper: "Mr. Gate" decides what is news, and what is not. In the second model, the news desk is conceived of as searching for news stories. Might this or that idea make a good story? Which tips are worth following up? In this latter case the "news" does not come to the journalist; rather, the journalist "tracks down" the news and reveals what s/he has found.

Everyday practice contains elements that may be interpreted according to either model. That is to say, they are in fact complementary. Still, we have yet to explain why some news values, norms and objectives (and not others) guide the selections, priorities and reporting of news desks.

\section{Two Pioneer Norwegian Contributions}

News criteria have been a focus in the field of mass communication research for quite some time. In Norway, the Institute for Peace Research proposed hypotheses and undertook empirical studies of the news process as early as the 1960s. Their work was influential far beyond Norway's borders. Its essence was encapsulated in a special issue of Journal of Peace Research (vol 2 no. 1) in 1965, in which Einar Østgaard has an article on factors influencing the flow of news and Johan Galtung and Marie Holmboe Ruge write on the structure of foreign news. The latter article has turned up now and then like a restless ghost in both Scandinavian and international discussions of so-called "news factors'.

Galtung and Homboe Ruge (1985:64-91) are primarily interested in the features of events that render them newsworthy. They liken the enormous number of events that occur any given day or week to the cacophony of broadcasting stations that fill the air waves. The question is, what of all this will catch our attention? Taking basic perception psychology as their starting point, they list a number of factors that will arouse the public's interest. These factors are then transformed into eight main hypotheses and four supplementary hypotheses as to qualities in events, viewed in relation to characteristics of the news media, that will catch our attention. ${ }^{3}$ 
The fundamental hypothesis is that the more of these criteria a given event satisfies, the more likely it is to be reported as news. The factors are not independent of one another; they covary to some extent.

Galtung and Ruge then used some of these hypotheses in an analysis of the manner in which three items of foreign news were reported in four Norwegian newspapers. Over the years, however, the "factors" and hypotheses put forward in this article have been taken to be a comprehensive theory of the news, supported by empirical research. This was hardly Galtung and Ruge's intention. I, myself, have experienced how Norwegian journalism students have taken the hypotheses as a kind of menu or checklist of news criteria and even as a sort of recipe for good news reporting.

Galtung and Ruge's intentions were in fact quite the opposite. Their article ended in a scathing critique of the news practices of western media, and a call for a new kind of journalism that focuses not on discrete events, but on longer-term processes and that pays attention to other phenomena than the affairs of big powers and elite politicians.

Stig Hjarvard (1995) offers a thorough and critical account of how Galtung and Ruge's article has been used and abused by mass communication researchers around the world, and I refer the interested reader to his work. Here I confine myself to pointing out the pitfalls of putting too much emphasis, and too one-sided emphasis, on the news value of the event itself. In reality, only very seldom do we encounter events that immediately, within the span of a day, have a force or amplitude that is so dramatic, so attention-getting and starkly delineated that they absolutely have to be reported as a national or international news events.

Keeping to the international arena. obviously brutal conflicts like those in Afghanistan and the Middle East gain extensive coverage. But, as we all know, the media seldom cover more than one or two conflicts or catastrophes at any given time. At the same time, they provide us with a steady stream of information about far less dramatic events and situations.

Einar Østgaard's article in the same issue of Journal of Peace Research has received far less attention. That is a shame inasmuch as Østgaard brings up more basic relationships in the news process than Galtung and Ruge's 'perception model'. Østgaard starts with the observation that the "free flow of news" is influenced by conditions that apply within the news production process as well as by factors external to it, not least political and economic factors. Østgaard specifies their influence at various stages of the news process.

One such 'external' factor is the news source: Governments and powerful institutions make a conscious effort to influence how the news is reported. Sources can also influence articles about economic conditions, but, Østgaard points out, little was known about this in 1965, as the subject was still terra incognita within the media research community. Another external factor in the case of foreign news is the circumstance that news services produce news stories as 'products' on a market, i.e., they should be produced at the lowest possible cost and sold to as many clients in as many countries as possible. In addition, the news enterprise's commercial rationale generally has considerable influence on editorial priorities. A third set of external factors are the priorities that arise out of the individual media company's editorial policy and market orientation.

In addition to these there are any number of factors that are part and parcel of the news process, but are bound up with the above-mentioned external factors. A market orientation implies a need to simplify stories so that they are comprehensible to a broad segment of the population. The news story is always a version of reality that is less complex than 
it might be. Secondly, stories intended for a broad segment of the public should contain some element that encourages identification, i.e., a well-known figures or familiar kind of events, something that is close to the reader/viewer in a cultural or geographical sense. The need to personify the news is closely related. Finally, we have sensationalism, which arises out of the tendency of news media to attach news value to situations characterized by conflict. In practice it is hard to understand journalistic news criteria without taking the news organizations' market strategies into account. News is literally "for sale".

\section{Market Niches and Editorial Market Strategies}

The media's market orientation is reflected in several ways. Commercial considerations are most apparent in the case of the popular press, where front- page headlines serve as adverts for the paper. A similar Norwegian example is VG Nett, the internet site of Norway's largest popular tabloid. In an interview ( $V G$ 9th June 2000) Torry Pedersen, then newly appointed editor-in-chief and general manager of VG Multimedia AS, characterized the three legs on which the news site stands: sports, celebrities and major news events:

He chooses sports for the young men, for they are the biggest users of Internet, and celebrities for the girls, because they are interested in things like that, and ... "We need to be better at news. VG Nett should be the best place for the latest on Sierra Leone, Jens Stoltenberg, Ole Gunnar Solskjaer and Aqua- Lene."

The formula is audience-oriented and commercial; the definition of an important news item is mainly that it is related to well-known people and celebrities and is popular in the niches and among the target audiences the site aims to reach. Plus room for "Sierra Leone," which - most likely in connection with a civil war or major crisis - can take its place alongside the latest trivia regarding Manchester United's Solskjaer and pop singer, Aqua-Lene.

'Tabloid news values,' whether in the press or on television, are a question of both the 'mix' and the angle and interpretive framework of the reporter. News beats that appeal to broad sectors of the public - scandals, crime, sports and pop culture - will be given very high priority relative to items about politics and public affairs (Sparks 2000). At the same time, the stories will be highly personified; they will impart sensations and emotions. Media dramaturgy has the aesthetic of melodrama, with a polarity between respresentatives of Good and Evil (Gripsrud 1992:88f).

Market-orientation in journalism is much more than commercial news media's indulging popular tastes and interests. Three factors that are of decisive importance in news selection and news production should be mentioned here:

1) the geographical area of coverage and type of audience

2) the competition between media and news enterprises

3 ) the budget allotted news departments, which is an expression of the company's commercial/financial objectives.

The area of coverage is the most obvious factor. The 'catchment area' of news media is, generally speaking, the most decisive factor regarding judgments of newsworthiness, of both events and personalities. It is not only a matter of proximity - that events nearby are more interesting than distant ones. Most newspapers are tailored to suit the reader- 
ship in a given district. Newspapers that address readers all over the country naturally have a broader news horizon. Certain English-language elite papers, such as Financial Times and Herald Tribune, have market-based reasons to carry considerably more international politics, etc., than newspapers that address a national readership.

In Norway, regional and local newspapers are omnibus papers; the contents are allround, and readers grasp most of the content. This is not the case in Great Britain, where the news market is segmented according to class, with "qualities" for the educated elites and tabloid "populars" for the masses. But the allroundness of Norwegian papers, I should note, is limited to news and reportage that has some bearing on the district (ranging from small towns to the nation) where the readers and advertisers are located.

For a local newspaper or local radio station, events that take place in another county or another paper's home market, even dramatic ones, may be considered non-events simply because they occur outside the area where the medium has its audience (and its advertisers). For example: A major traffic accident that occurs just east of the Lysaker River, i.e., a couple of hundred meters outside the Baerum city limits, will generally not interest the local newspaper in Baerum (Asker og Baerums Budstikke) unless one or more of the people involved resided in Asker or Baerum, the paper's area of coverage. Or, as the editor of Troms $\varnothing$, a paper that aspires to be the local paper of the city of Troms $\varnothing$, puts it: "If there's a murder in Finnsnes, what's that to us? "4 In the local newspapers owned by the Orkla Group, it is the executive board, not the editor-in-chief who decides where the papers' branch offices will be located. The relative concentration of readers and, thus, the commercial interest to advertisers count more than whether there are interesting news sources or objects of coverage in the area.

An example from Aftenposten, a paper in the Schibsted chain, illustrates the importance of this latter factor. In the late 1980s, Editor-in-Chief Egil Sundar tried to turn Aftenposten, a regional newspaper in Oslo and Eastern Norway, into Norway's leading nationally distributed newspaper. Part of Sundar's strategy was to make it possible for readers anywhere in Norway to subscribe to the Saturday edition. This required an earlier printing deadline and entailed considerable extra distribution costs, which were not covered by any increase in advertising revenue. The project was sabotaged by the commercial departments, which failed to balance the costly distribution with advertising sales on a national level, as Sundar's ambitious scheme had envisaged. Shortly thereafter, Sundar was forced to leave his position, and Aftenposten returned to its original market concept. ${ }^{5}$

Nationally distributed newspapers, with readers throughout Norway, de facto fill different news niches and serve different market segments. Norway's two popular tabloids, $V G$ and Dagbladet, appeal to 'everyone' with a combination of news and diversion/entertainment. A strong rivalry prevails between the two.

Right-wing, neoliberal business newspapers like Dagens Naringsliv and Finansavisen operate on a different market. They specialize in economic news of direct interest to top and middle management in both private enterprise and the public sector, whereas subjects like traffic accidents, violent crime and sports are excluded. Other niche papers have more the character of opinion papers. Vårt Land (a conservative Christian paper in religious matters, more social-liberal in politics), Nationen (with an emphasis on Norwegian news outside the metropoles and against Norwegian membership in the European Union), and Klassekampen (a socialist newspaper, likewise against Norwegian membership in the Union) are more allround than the business papers and address mainly politically and ideologically aware readers who feel a need for a complement to the local press. 
Traits peculiar to different news media also play in. In the case of television newscasts, the desire to tell a good story with live footage often decides what is selected for treatment and becomes news. If a story cannot be visualized - be it with no more than a still or portrait photo - it will tend to be placed toward the end of the queue, if it is included at all (Sand \& Helland 1998). This mechanism is also well-known among PR agents: an offer of 'live footage' can lower the news threshold.

Having an exclusive, i.e., being the only medium to cover a story, is an advantage in competitive situations. News organizations compete by developing stories on their own, and they will often ignore a story that many other media already have covered or are covering. Editors of newspapers, which appear only once a day, will furthermore try to judge how well-known a story may be by the time readers confront it in their product. If radio stations have carried a story a half day before the paper comes out, it may be regarded as 'old hat' or a 'non- event', even in nationally distributed papers. The same applies to other media, as well. If the news department of NRK (Dagsrevyen) or TV 2 feel they are alone in covering a story, they will be strongly motivated to make it the top of the evening news. The emergence of net media has heightened 'old' media's motivation to cultivate their identities by carrying exclusive stories, background information and features that have not yet been published by others.

A third factor, then, is the budget news gathering and reporting is allotted. Every editor knows the possibilities and constraints the size of one's budget implies, yet it is little discussed publicly. "Among the most remarkable aspects of the folklore of the press is the absence of reference to money, " Herbert Altschull observes in Agents of Power (1984:253). Textbooks in journalism education seldom have very much to say about the relationship between how media are financed and their product characteristics. In Melvin Mencher's News Reporting and Writing (1994), only two of 600 pages mention the influence finances can exert on content, news priorities and journalists' choice of sources. Be that as it may, capitalization of the media has meant that journalists increasingly are required to be managers, and the managers focus more and more on budget control and reporters' productivity rather than on winning professional recognition.

Every news chief knows that the news can be produced at different levels of expense. Cheapest are items based on rewrites of press releases, reports from press conferences and other situations where news sources serve information on a silver platter. Somewhat more demanding of time and effort - and therefore more costly - are follow-ups of stories that have already broken, e.g., contacting alternative sources for comment on some political initiative or statement to the press by a news source. If the news desk relies heavily on news of its own making - following up tips, developing its own reportage ideas and putting research into a solid background article - its costs will be high. Even more costly are investigative reporting and series. Reluctant sources and closed doors only add to the cost of such ventures.

Most news desks will also buy material from one or more news services. Since these services are subscribed, it is most economical to make use of the material the service provides as copy; it is much more costly to use it only as background and reference material for one's reporters.

Studies of news media have found that, due to shortages of staff and budget constraints, news desks generally have to make sure they develop contacts with organized, bureaucratic sources - e.g., the police, the courts, traffic control centres, local administrators and political bodies - reliable sources of a steady stream of information that can easily be converted into news copy. Active, self- reliant news gathering costs. Offensive 
offers of journalistically processed information from resource-rich sources are a daily temptation. Precisely such 'information subsidies' play a central part in professional agents' media strategies (Gandy 1982; Allern 1997).

By the same token, some kinds of potential news stories are left aside, not because they lack relevance, but because they require 'digging' and journalistic resources: time, staff and money. Budget-consciousness means that certain kinds of news stories, those that cost little to produce, tend to have an easier time making their way into news columns and newscasts.

The traditional news criteria mentioned above may therefore be supplemented with a set of "commercial news criteria":

- The more resources - time, personnel and budget - it costs to cover, follow up or expose an event, etc., the less likely it will become a news story.

- The more journalistically a news source or sender has prepared a story for publication (the costs for such treatment being borne by the sender), the greater the likelihood that it will become news.

- The more selectively a news story is distributed, e.g., in a manner that allows a journalist to present the story as his or her own work, under a personal byline, the more likely it will become news.

- The more a news medium's strategy is based on arousing sensations to catch public attention, the greater the likelihood of a 'media twist', where entertaining elements count more than criteria like relevance, truth and accuracy.

In the following, we shall consider two case studies, both taken from a content analysis of a variety of Norwegian newspapers ${ }^{6}$, that illustrate market mechanisms like these in news production.

\section{Case study 1. The front-page news in three Norwegian newspapers}

Verdens Gang (VG), Dagens Naringsliv and Vårt Land are all national newspapers, and they are national in two senses of the word. First, they emphasize news that is calculated to interest readers in different parts Norway. Secondly, they have managed to attract readers throughout the country.

At the same time, they are quite different kinds of papers. $V G$ is a street-sale tabloid with Conservative leanings; it is the leading exponent of 'tabloid culture' in Norway. $V G$ also has the largest circulation among Norwegian newspapers (375,983 in 2000). Dagens Nceringsliv is a specialized newspaper that primarily addresses readers in the business community and public administration, i.e., readers with a particular interest in news and data on the economy and the finance market. The paper's ideological orientation is neoliberal. It had a circulation of 71,364 in 2000. Vårt Land is, as mentioned above, a Christian newspaper, middle-of-the-road in its politics. It had a circulation of 29,578 in 2000.

During the reconstructed sample week of the present study, the front pages of the three papers carried 124 items (including 'kickers' that refer the reader to the inside pages). ${ }^{7}$ Vårt Land had by far the most items, $V G$ the least. Despite the fact that all three papers are published in Oslo and address a nationwide readership, none of the items was carried in more than one paper. The differentiation was extreme. 
All the items in $V G$ were highly dramatic: acts of violence and other life-and-death situations, blackmail, and crises. 'The drama of everyday life' is part of the paper's news concept. One of the front pages is about a young woman who, according to the paper, was forced by her driving instructor to pose naked on a motorcycle. To underline the 'scandal', the paper illustrates the story with a photo of the woman, naked, on the bike. Capitals in the headline reinforce the sensational aspect. Otherwise, a front page in $V G$ typically features a prominently placed photo of one or another celebrity, who in most cases figures in a very minor story somewhere in the inside pages.

The front pages of Dagens Naringsliv live up to the paper's name (Business Day) and report purchases, sales, interest rates, the stock market, options and various CEOs who have got the sack. Minor front-page headlines, too, are about economic aspects, but here the scope broadens to include branches like the media, cultural institutions and pop culture.

As might be expected, Vårt Land presents a quite different image of reality than the other two papers. Front-page stories in this Christian newspaper are about church life and religion, cultural life, health and human relations. The minor items, and particularly the 'kickers' provide a catalogue of the issue's contents.

The selection of news presented on all three papers' front pages clearly reflects the papers' respective editorial standpoints and market orientations. Few news stories are, in themselves, significant or important enough to merit front-page coverage in all three papers. It takes a major accident, a protracted mass strike or a change of Government for an event to be given the same news priority. All three papers put a lot of effort into developing their own news stories, and stories worked up by the paper's own staff are featured prominently. This is how the papers go about developing an identity in competition with other papers and media.

The front pages of these three papers represent three distinct news cultures. This is not to say that the journalists working for the respective papers have fundamentally different ideas about abstract news values like proximity and identification, significance and sensation. Over the years, the popular press in Oslo has in fact recruited many a reporter from Vårt Land. But the papers' market positions and orientations toward their readership differ in the extreme. Consequently, the editorial strategies differ. This is what permeates "the woodwork" in the newsroom and molds a paper's news culture.

\section{Case study 2. The Bodø press: the same news in both papers?}

Bodø is a coastal town in northern Norway. For over sixty years, two local papers, Nordlands Framtid and Nordlandsposten, have been strong competitors in this area of Nordland County. In 2000, Nordlands Framtid, a daily with Social Democratic political roots, had a circulation of 19,337, and Nordlandsposten, a daily with Conservative political leanings, had a circulation of 15,448. In February 2002, the two papers were closed down after an agreement between their owners, the group companies A-pressen and the Harstad Tidende group/Schibsted. On the ruins of the two rivals a single new paper, Avisa Nordland, co-owned by the two groups, has arisen. The new paper will have a monopoly on the local market, which will make it easier to milk the advertising market. The owners appear to have wasted no time; according to the net edition of the professional paper, Journalisten (22nd February 2002), local advertisers in Bodø are protesting a rise in advertising rates. The agreement also provides for collaboration in advertising sales between the two group companies in other parts of the North. 
Before Nordlands Framtid and Nordlandsposten became newspaper history, I performed an analysis of their news material (Allern 2001a). Due to the competition between them, both papers carried much more news copy than was common among newspapers of their size. It seemed reasonable to expect that the two competitors in this relatively small community would carry the same kinds of news. In one sense they did: the editorial pages in Nordlands Framtid and Nordlandsposten were organized more or less the same way, and the two papers allotted roughly the same space to local news, sports, culture and so forth. But did they also carry the same news stories?

Table 1 shows the frequency of overlap in various content categories. The basis of the comparison is articles in the inner pages, front-pages excluded. The number of news items $(\mathrm{N})$ is the net of the total number of articles in the two papers, minus the number of items referring to the same news event. ${ }^{8}$ The category "Domestic and local news" includes articles on politics/public administration, the economy/business, health/education/ the environment, traffic/accidents, crime/justice, and other local news that do not concern sports or the Arts. Sports, the Arts and foreign news are generally carried on separate pages in both papers, but articles on other pages are included in the respective categories where appropriate. The material does not include features (principally in the Saturday edition) and commentary (leaders, columns, letters-to-the-Editor).

Table 1. The news copy (principal articles, secondary articles and news briefs) in a reconstructed news week in Nordlands Framtid and Nordlandsposten. Overlap in news coverage as a percentage of all news items and the categories, Domestic and local news, Sports, The Arts, and Foreign news

\begin{tabular}{lcc} 
Category & Overlap (\%) & $(\mathrm{N})$ \\
\hline Domestic and local news & 7 & $(589)$ \\
Sports & 8 & $(118)$ \\
The Arts & 11 & $(104)$ \\
Foreign news & 13 & $(61)$ \\
Total & 8 & $(872)$ \\
\hline
\end{tabular}

The gross number of articles in the category domestic and local news was 633, with somehwat more in Nordlands Framtid than in Nordlandsposten. Forty-four of these articles were about events that both papers covered, which yields a net total of 589 news events. Of this remainder, 50 per cent were exclusive to Nordlands Framtid, and 42 percent exclusive to Nordlandsposten. Seven per cent appeared in both papers. In the case of sports, 8 per cent of the events were reported in both papers, whereas the shares for the Arts and foreign news were 11 and 13 per cent, respectively. On average, only 8 per cent of the news events appeared in both papers.

The few stories that both papers covered on the same day were out-of-the- ordinary events. Aside from a nationwide politically motivated strike, they mainly have to do with local crime and accidents. The papers put considerable resources into hunting out and developing their own news to a much greater extent than thinking up their own 'angle' on one and the same story. The same pattern was found in sports and the Arts, where both papers covered mainly major athletic events (recaps in the Monday edition), concerts and meetings. 
The tendency to choose different news items was also apparent in the papers' use of wire service material. The papers carried relatively little foreign news, particularly in Nordlandsposten, and what they carried was mainly news service copy from the Norwegian News Agency, NTB. Still, few items were carried in both papers. This may be due to the fact that the menu of items was long and space in the papers limited, which means that a few choices on the part of the respective desk editors could result in quite different priorities. Whatever the case, it is a reminder of how differently editors can judge the significance, relevance and interest of the stories that pass across their desks.

Even though the two papers were published in the same town and competed for the same readers, they chose to feature to a surprising extent quite different news events and figures. Obviously, they may have followed up each other's news a day or two later, a possibility not investigated in the present study. But inasmuch as news desks tend to avoid 'old news', particularly if their competitors have carried it, such follow-ups were probably not frequent.

An overall characteristic of news, and a major factor behind such a pattern, is that surprising and dramatic "happenings" are far fewer, and therefore play a lesser role, than is generally assumed. News reporting deals for the most part with many other kinds of events: the presentation of plans and projects, reports from meetings and other gatherings (there are generally any number to choose from), and various actions and reactions in the realm of local politics. Opinion, e.g., complaints in the wake of an occurrence or a situation or reactions to others' views, is yet another facet of news journalism.

Another interesting characteristic of the two papers in Bodø is that they, as a consequence of their intense rivalry, had more pages and richer contents than most local newspapers. Indeed, they were on a par with $V G$, Norway's largest. Meanwhile, they were produced by only a fraction of the staff. ${ }^{9}$ Staff members' productivity was extremely high.

Both papers held their own, economically speaking, but they did not turn much of a profit or make much in the way of group contributions. The new local monopoly paper will make it easier for the owners to reap a fatter profit. Whether this will mean more resources at the disposal of the new editorial staff (which, of course, is much smaller than in the former papers together), as some hope it will, remains to be seen. One thing is certain: news coverage in the district will be far less comprehensive than it was.

\section{The Political News Beat}

As noted earlier, the notion of news media as mainstays of political democracy has been central to the norms of news institutions and journalism as a (quasi)profession. In a study of the position of national political coverage in Norwegian media, I found that what happens in Parliament, the parliamentary parties and other central political processes is given relatively high priority in the media's deployment of staff and internal organization (Allern 2001b). Just under 300 journalists and editors attached to 42 Norwegian news desks cover national politics. Many Norwegian newspapers, news bureaux and broadcasting organizations have political news departments and commentators. Smaller newspapers rely on two news services for most of their coverage of national politics.

Political journalism has been held in high esteem within the news business. Partly because political reporting requires knowledgeability and journalistic competence, but also because journalists who cover politics frequent the corridors of power and meet influential figures. If journalism is still a male-dominated occupation, political journalism is even more so. 
The organization and management of news departments reflects the ideal of maintaining a distinction between political news journalism and political commentary. Consequently, political reporting and commentary sort under two different editors. Political editors are the 'opinion generals', whereas the head of the political news desk, who answers to the editor of the news department, commands the troops of political reporters.

One consequence of this division is that political journalism today is subject to the competition for the same space and air time as other news journalism. Most Norwegian newspapers no longer have pages reserved for political news (in contrast to, say, business news, culture and entertainment, and sports). The same is true of politics in television newscasts. What is assigned political 'importance' or 'significance' is judged in relation to an overall mix of contents that includes accidents, crime, business, sports, and entertainment. At some junctures (e.g., parliamentary impasses, reshufflings of the cabinet or internal strife in one or another party) the public may be served overdoses of certain types of political news that lend themselves to dramatization and personification. News items about political processes often lose out in the competition because things that immediately attract and interest readers and viewers are valued more highly. Similar considerations limit the amount of international news that media carry.

This is most probably one of the main reasons why political news, despite the relatively many journalists who work in this area, tends not to be accorded very much space in the nationally distributed Norwegian press. In my content analysis of ten Norwegian newspapers, nationally distributed VG, Dagens Naringsliv and Vårt Land (all published in Oslo) devoted least space to politics and public administration, whereas the smallest local newspapers gave such material rather high priority (Allern 2001a). This is because these latter papers generally cover what happens in local government (city and county councils). In contrast, parliamentary debates must reach the boiling point, cabinets fall to pieces, or party brothers and sisters be at each other's throats before political news is given priority in major national papers. The dilemma is that political journalists, to win out in the competition, are forced to play up political gamesmanship and the drama of power-struggles, whereas decisions made in public administration and processes that go on behind the scenes in politics tend to be left aside.

What is more, news desks seldom have night editors with political savvy and experience. Therefore, they tend to follow a course that best corresponds to general, marketoriented news values. News editors are largely preoccupied with seeing to it that 'we' do not miss anything that our competitors manage to cover. Both politicians and political reporters whom I have interviewed say that on occasion even major interviews that have taken a lot of time and effort to arrange and carry out will be put aside because "the desk" could not fit them into the day's 'mix' of news items. Journalists learn from experience what kinds of copy win editors' favor. They learn quickly.

A good share of the journalism concerning national politics in Norway today focuses on power-struggles between the Government and the Opposition, the debate among parties in the Parliament and conflicts within the respective parties. In practice, this means that there is little room for the issues that have significance for people in their daily lives; what is more, it means that the images of reality political journalism imparts derive from the political elite and its immediate surroundings. Inasmuch as leading news organizations set their priorities in this manner, the political agenda of the press becomes relatively uniform. 
This in turn gives rise to a strong herd mentality among journalists, a kind of conformity of attitudes and ideas as to who and what are the prize trophies in the political news hunt.

\section{Journalistic and Commercial News Criteria}

To sum up, then. Journalistic news values formulated in catchwords like timeliness, relevance, identification, etc. are so abstract that, taken alone, they tell us little about actual priorities and choices. They assume meaning only when placed in the context of the medium's orientation to its readership or audience or, in other words, its market orientation and editorial market strategy. All kinds of media and news companies that operate on a capitalistic market need a strategy of this kind, even public service broadcasters and, for that matter, socialist newspapers and miscellaneous media that are run on an ideological or purely idealistic basis. At the same time, there are significant differences between news organizations that are primarily 'idea-driven' and those whose principal purpose is to turn a profit for their owners.

In the case of open stock companies, the prime aim must be to yield a maximum return on invested capital. In such companies, success vis-à-vis a given market segment or 'target audience' is only a means to serve the advertising market, to secure a profit, and to enhance the company's standing on the stock exchange. Editorial costs are evaluated with the same considerations in mind. This can have a profound influence on the kind of news a medium carries and on the kinds of sources that are given priority. Editors employed in these companies know what is expected of them. Those who fail to 'deliver' soon discover that owners not only have the power to hire, but also to fire, at will. As in the rest of Fenno- Scandinavia, the role of Norwegian news media as power-brokers is no longer a matter of acting spokesman for or supporter of one or another political party. Today's media concerns are generally on a good footing with the powers that be. They hire Editors-in-chief that stand for reliable, predictable consensus values and strive for political alliances that guarantee freedom of enterprise, political stability and a capitalfriendly investment climate.

In some cases - when, for example, media appeal to elite audiences - commercial market objectives will allow room for quality journalism that requires considerable editorial resources. In Norway, the business newspaper Dagens Naringsliv sometimes shows itself capable of investigative journalism that not only wins it repute in professional circles but also attracts new readers. But far more typically, particularly when the advertising market is slow, the paper will let journalists go and reduce other editorial costs to make sure that it turns a profit. Local Norwegian newspapers in the Orkla and A-pressen chains that consistently return solid profits have been subject to similar cutbacks that have made it difficult, if not impossible, to undertake investigative reporting or more ambitious reportage projects. Instead, the papers have to rely on 'assembly line journalism', i.e., the kind of reporting that can be done from a desk, which necessarily implies a reliance on institutional, bureaucratic news sources.

There are, however, limits to how far commercialization and the profit motive can go. Even public stock media companies are dependent on a modicum of journalistic creativity, originality, and a willingness to work hard. Readers and audiences, too, have qualitative expectations of the news as an institution. This has given, and will continue to give rise to sharp conflicts between, on the one hand, priorities concerned with "maintaining the institution of news journalism" and, on the other hand, the demands of actors in the finance market. 


\section{Notes}

1. In Governing with the News, Cook discusses the role of news media as political institutions and whether or not journalists can be conceived of as political actors. This discussion falls outside the bounds of the present article. I have, however, followed up the perspective in a recent book, Flokkdyr på Løvebakken? Sфkelys på Stortingets presselosje og politikkens medierammer [Herd journalism? Spotlight on the Norwegian parliamentary press lobby and the media's framing of politics] (Allern 2001b).

2. These tasks are frequently characterized as "functions of the media'. For example, in NOU 1983:3 Massemedier og mediepolitikk [Mass media and media policy]; NOU 1992:14 Mål og midler i pressepolitikken [The means and ends of press policy] ; St. meld Nr. 32 1992/93 Media i tida [Contemporary media]. Norwegian authorities and policy researchers have been inspired by the ideas expressed in the Swedish studies that preceded the introduction of a system of state subsidies to the press in the 1970s. Swedish media scholar Bengt Nerman (1991) rightly views the press' and authorities' embrace of the notion of a "mission" as corporative doctrine. For a critique of functional theories of news media, see Allern (1996:47-49).

3. 1)The media will give priority to stories that have a time-span that is consonant with the tempo of the medium, and the media prefer events to processes ("The building of a dam goes unnoticed, but not its inauguration."). 2) An event must have a certain "amplitude", i.e. an airplane crash resulting in 100 casualties will be given priority over a traffic accident in which no one was seriously injured (threshold). 3) The event should be clear-cut and easily grasped (no ambiguity). 4) The event should be perceived as relevant to the cultural circle to which the medium caters (meaningfulness). 5) News tends to be about certain familiar types of events (consonance). 6) Familiar phenomena that nonetheless occur unexpectedly will be carried (surprise). 7) Once an event has been given coverage, it will most likely continue to get coverage, for a while at least. As Galtung \& Ruge put it, referring to the broadcasting metaphor: "If one signal has been tuned in to the more likely it will continue to be tuned in to as worth listening to." (continuity) 8) Newsdesks are concerned about the balance of the content they carry (e.g., between foreign and national news); that is to say, newsworthiness is dependent on the overall assortment of items already carried (composition). Galtung \& Ruge consider the above factors more or less universal; they do not vary between different political and cultural contexts. The following four factors, however, are culturally determined and are particularly relevant for western media's treatment of foreign news. News tends to be about 9) elite nations and 10) elite individuals ("top dogs" as Galtung \& Ruge put it); 11) stories are mainly about people, and 12) events of a negative character take priority.

4. Personal communication with the author. Finnsnes is roughly $60 \mathrm{~km}$ south of Troms $\varnothing$.

5. Egil Sundar's departure from Aftenposten was the consequence of several factors. A principal cause was his use of the paper to campaign for the formation of a Conservative-oriented coalition government. This was a marked departure from the 'consensus' or 'middle-of-the-road' profile the owners, not least for commercial reasons, sought to maintain.

6. The study, reported in Allern (2001a), analyzes ten Norwegian newspapers. Each newspaper is represented by one issue per day of the week (two issues in the case of papers appearing three days a week), dates chosen at random in the interval, October 1998 - February 1999. For details of the sampling and analytical procedures, see the report.

7. The analysis includes issues six days of the week, Monday-Saturday. $V G$ 's Sunday edition has been excluded.

8. The "same news event" may be an accident, a decision on the part of the city council, the grand opening of a bridge, the announcement of a proposal, coverage of a soccer match, and so forth.

9. Whereas $V G$ had 342 editors and journalists, including desk typographers, in their employ in 1999 (the year of the study), Nordlands Framtid had 37 and Nordlandsposten 32.

\section{References}

Allern, S (1996) Kildenes makt. [The power of news sources]. Oslo: Pax.

Allern, S (1997) Nar kildene byr opp till dans. [When news sources ask you to dance]. Oslo: Pax.

Allern, S (2001a) Nyhetsverdier: Om markedsorientering og journalistikk i ti norske aviser. [News values: On market orientation and news reporting in ten Norwegian newspapers]. Kristiansand: IJ-forlaget.

Allern, S (2001b) Flokkdyr på Løvebakken: Sфkelys på Stortingets presselosje og politikkens medierammer. [Herd journalism? Spotlight on the Norwegian parliamentary press lobby and the media's framing of politics]. Oslo: Pax. 
Altschull, H (1984) Agent of Power: The Role of the News Media in Human Affairs. New York: Longman. Cook, T (1998) Governing with the News: The News Media as a Political Institution. Chicago/London: The University of Chicago Press.

Enzensberger, H M (1974) The Consciousness Industry. New York: The Seabury Press/Continuum.

Galtung, J; Ruge, M H (1965) The Structure of Foreign News. Journal of Peace Research 2:1.

Gandy, O T (1982) Beyond Agenda Setting: Information Subsidies and Public Policy. New Jersey: Ablex.

Giddens, A (1984) The Constitution of Society. London: Polity Press.

Gripsrud, J (1992) The Aesthetics and Politics of Melodrama. In Dahlgren, P \& Sparks, C (eds.) Journalism and Popular Culture. London: SAGE.

Helland, K (1999) Nyhetsinstitusjonens tekster [Texts of the news institution]. In Larsen, P \& Hausken, L (eds.) Medier(2): Medier - tekstteori og tekstanalyse. Bergen: Fagboksforlaget.

Hjarvard, S (1995) Internationale TV-nyheder [International news on television]. København: Akademisk Forlag.

Mencher, M (1994) News Reporting and Writing. Madison: Brown \& Benchmark. (6th ed.)

Murdoch, G (1982) Large Corporations and the Control of the Communication Industries. In Gurevitch, M et al. (eds.) Culture, Society and the Media. London: Routledge.

Nerman, B (1991) Makt och metod. Kring massmedier och maktutredning [Power and methods: on mass media and studies of power]. Nordicom Information 4.

Njaastad, O (1999) TV-journalistikk [Television journalism]. Oslo: Gyldendal/Ad Notam.

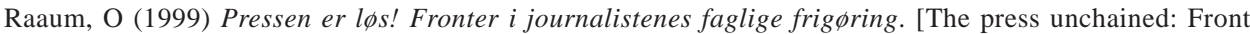
lines in the professional liberation of journalists]. Oslo: Pax.

Sparks, C (2000) Introduction: The Panic over Tabloid Values. In Sparks, C \& Tulloch, J Tabloid Tales. Lanham/Boulder/New York/Oxford: Rowman \& Littlefield.

Tuchman, G (1973) Making News by Doing Work: Routinizing the Unexpected. American Journal of Sociology 78: 110-131.

White, D M (1950) The Gatekeeper: A Case Study in the Selection of News. Journalism Quarterly 27.

Østlyngen, T \& Øvrebø, T (1998) Journalistikk: Metode og fag. [Journalism: Methods and profession]. Oslo: Gyldendal/Ad Notam.

Østgaard, E (1965) Factors Influencing the Flow of News. Journal of Peace Research 2:1. 